\title{
The Evolution of the Temple Plan in Karnataka with respect to Contemporaneous Religious and Political Factors
}

\author{
Shilpa Sharma ${ }^{1}$, Shireesh Deshpande ${ }^{2}$ \\ ${ }^{I}$ (Associate Professor, IES College of Architecture, Mumbai University, India) \\ ${ }^{2}$ (Professor Emeritus, RTMNU University, Nagpur, India)
}

\begin{abstract}
This study explores the evolution of the plan of the Hindu temples in Karnatak, from a single-celled shrine in the 6th century to an elaborate walled complex in the 16th. In addition to the physical factors of the material and method of construction used, the changes in the temple architecture were closely linked to contemporary religious beliefs, rituals of worship and the patronage extended by the ruling dynasties. This paper examines the correspondence between these factors and the changes in the temple plan.
\end{abstract}

Keywords: Hindu temples, Karnataka, evolution, temple plan, contemporary beliefs, religious, political

\section{Background}

\section{INTRODUCTION}

The purpose of the Hindu temple is shown by its form. (Kramrisch, 1996, p. vii)

The architecture of any region is born out of various factors, both tangible and intangible. The tangible factors can be studied through the material used and the methods of construction used. The other factors which contribute to the temple architecture are the ways in which people perceive it and use it, to fulfil the contemporary prescribed rituals of worship. The religious purpose of temples has been discussed by several authors. Geva [1] explains that a temple is the place which represents the meeting of the divine and earthly realms. Kramrisch [2] specifies that the "looking at the temple" is an important purpose to be fulfilled, that of being recognized as a place of sacredness. Apart from the religious aspect, the temple represents the cultural values of the region [3]. In South India, the Deity took on the characteristics of royalty. This indirectly manifested the power of the king [4], [5]. Thus, Michell [6] asserts that the visual impact of the monumental temples are a sign of political aspirations and in the show of power, as well as a source of authority, which is seen through their complexity and ornateness.

\section{Aim of the Study}

The temple plan has been seen to change with every successive dynasty and its respective social condition, this change has been in terms of size, scale and complexity. This paper aims to explore the evolution of the plans of the temples of Karnataka, from the $6^{\text {th }}$ to the $16^{\text {th }}$ centuries, with respect to the contemporaneous religious and political factors.

\section{Methodology and Scope}

The study will consider the temple plans simultaneous with the factors which are seen to have affected their evolution. The plans are from previously well-recorded sources. Being historical in nature, the information regarding the affecting factors is secondary in nature. This study does not go into the materials and methods of construction used.

Note: The plans are meant to indicate evolutionary aspects. They are neither shown to scale, nor are they in proportion with one another.

The legend to be followed for all the temple plans in this paper is as follows:

Garbha-grha

Mandaps 


\section{Parts of the Temple}

\section{THE HINDU TEMPLES OF KARNATAKA}

By the $6^{\text {th }}$ century, idol worship was prolific in Hinduism. The garbha-grha (sanctum) housed the Deity in form of His idol. This is the most sacred space and the most essential as the temple cannot exist without it [7]. The sanctum is crowned by the shikhar (spire) which is the tallest part of the temple's superstructure. The entry into the temple is through the ardha mandap (pillared porch). The door directly faces the garbha-grha and leads into the main hall or sabha mandap. This is the hall for public congregation. Within this is situated the ranga mandap, a raised platform for the performance of sacred music and dance, as an offering to the Deity. The entry into the garbha-grha is through the antaral (vestibule). This architecturally separates the garbha-grha from the rest of the temple. The temple is either roofed with flat, sloping, corbelled or domical roofing. None of these roofs supersede the main shikhar. All the spaces which belong to a single structure are invariably arranged along the longitudinal axis running between the ardha mandap and the garbha-grha. There is a definite alignment to the grid which is made evident by the columns.

\section{Case studies of Hindu temples of Karnataka}

$12^{\text {th }}$ century inscriptions in Kannada refer to Karnataka as "Kuntala Desha" [8]. In South India, the surviving stone temples are seen only from the $7^{\text {th }}$ century CE. The following six dynasties form the chronological background of this paper (Table 1):

Table 1: The six ruling dynasties of Karnataka $\left(6^{\text {th }}\right.$ to $16^{\text {th }}$ centuries CE) [66]

\begin{tabular}{|l|l|l|}
\hline No. & Dynasty & Time Period \\
\hline 1 & Badami Chalukyas & $535-757$ CE[9] \\
\hline 2 & Rashtrakutas of Malkhed & $750-973$ CE [10] \\
\hline 3 & Kalyan Chalukyas & $973-1198$ CE [11] \\
\hline 4 & Hoysalas of Dwarasamudra & $1000-1346$ CE [12] \\
\hline 5 & Pre-Vijaynagar (Early Sangama) & 1336 to 1485 CE [13] \\
\hline 6 & Vijaynagar (Saluva and Tuluva) & $1485-1570$ CE [14] \\
\hline
\end{tabular}

\subsection{Badami Chalukyas ( $535-757 \mathrm{CE})$}

Soundara Rajan [15] tells us that the Badami Chalukyas brought about a phase of peace and unity, which led to religious harmony and encouraged arts and crafts. They were influenced through cultural interaction with the Pallava and Chola dynasties of Tamil Nadu and Andhra Pradesh. Soundara Rajan [16] further explains that The Badami Chalukyas reinstated Puranic Hinduism over prevalent Buddhism. This gave impetus to idol-making, and thus to temple-building.

\subsubsection{Temples of the Badami Chalukyas}

The activity of building temples in the northern and southern parts of India, were simultaneous during the late 6th and early 7 th centuries. These stone temples were responsible for setting up the fundamental plan of the temple, which consisted of the garbha-grha and the pillared porch arranged axially. Some architectural texts were already in practice at this time, like the Manasara (500 to $700 \mathrm{CE}$ ) [17]. At this time, Aihole was an important mercantile centre, with little political influence. The large number of shrines are due to the patronage of this community [18] during the $6^{\text {th }}$ and $7^{\text {th }}$ centuries. The first phase is seen at the 6th century Konti Gudi group of temples, followed by the Lad Khan at Aihole (Fig. 1). These temples consist of a large hypostyle hall, which were used as a place of meeting by the merchants [19]. The garbha-grha is a cell attached to the rear wall [20] and hence does not accommodate a pradakshina path. The next stage of development is seen in temples such as Huchchimali Gudi, Aihole (Fig. 2). This has an enclosed hypostyle hall (goodh mandap). The garbhagrha is now detached from the rear wall so that the pradakshina path can be formed [21]. A marked effort to adapt the apsidal plan of the Buddhist chaitya is seen in the Shiva temple at Chikka Mahakut ( $7^{\text {th }}$ century) near Badami and the Durga temple ( $8^{\text {th }}$ century) at Aihole (Fig. 3) [22]. Both temples have an enclosed ambulatory. Though the addition of the shikhar may have been an attempt to "Hinduize" this plan, it was abandoned as inadequate for the growing ritualism of Hindu worship [23]. So far, in all the plans, the width of the garbhagrha is seen to be the same as the colonnaded hall outside, separated with only a wall with a single door. The antaral (vestibule) is seen from the Pattadakal temples of the 7th to 8th centuries (Fig. 4). This was a definite architectural separation of the garbha-grha [24]. However, the pradakshina path, though a part of the rituals, does not seem to be a mandatory part of the temple plan as yet. 


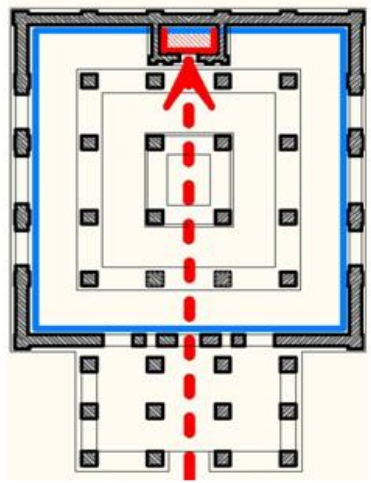

Figure 1: Plan of the Lad Khan temple, Aihole (550-600 CE)

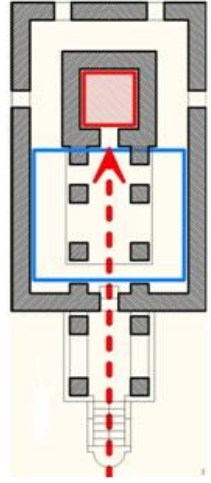

Figure 2: Plan of Huchchimali Gudi, Aihole ( $6^{\text {th }}$ century)

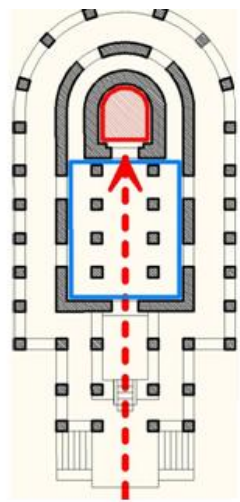

Figure 3: Plan of Durga temple at Aihole $\left(8^{\text {th }}\right.$ century)

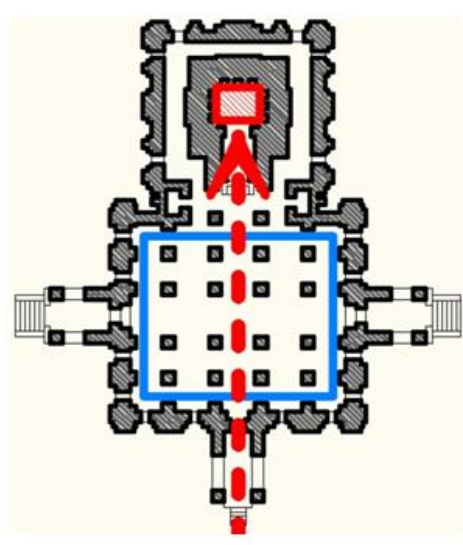

Figure 4: Plan of Virupakshatemple, Pattadkal (740 CE)

\subsection{Rashtrakutas of Malkhed (8-10 CE)}

Like the preceding dynasty, The Rashtrakutas were one of the strongest dynasties of India which helped promote culture and the arts and crafts [25]. Hinduism further strengthened its roots, and was practised alongside Jainism. With the advent of Adi Shankaracharya and the Bhakti movement, Vedic practices declined. The Puranas presented the saguna or the visible form of God, as a focus for devotion. The idol was given importance by treating it like royalty- with food (naivedya), music and dance (ranga bhog) and numerous other rituals of service which were performed by Brahmins [26], [27].

\subsubsection{Temples of the Rashtrakutas}

The importance of temples grew since the Puranas prescribed pilgrimages to various tirthas (sacred places) [28] and there was a rise in temple-building [29]. There were several architectural changes seen. The size of the outer mandap increased considerably in relation to the garbha-grha, to accommodate larger congregations. The antaral constricted in width, emphasizing the divide between the sanctum and the rest of the temple. In some temples, multiple shrines are seen (Fig. 5), to accommodate the growing pantheon. The mandaps are square in shape. The pradakshina path is not seen as a compulsory feature (Fig. 6).

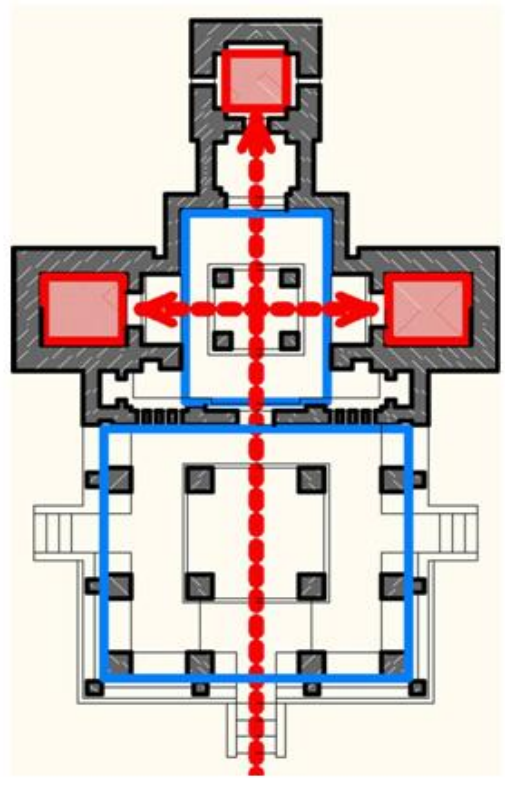

Figure 5: Rachi Gudi, Aihole ( $8^{\text {th }}$ century) with multiple shrines [72]

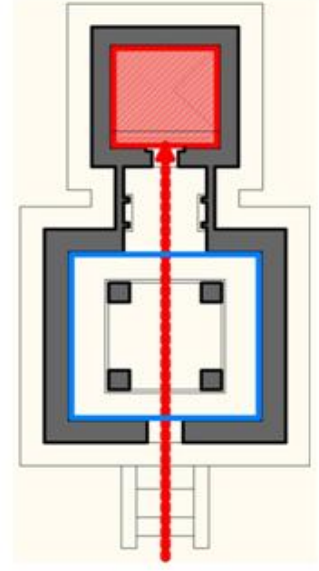

Figure 6: Chandrashekhar, Pattadakal $\left(8^{\text {th }}\right.$ century) [73] 


\subsection{Kalyan Chalukyas (10-12 CE)}

The Kalyan Chalukyas were the descendants of the Badami Chalukyas. The earlier religious norms persisted. The worship of the Trinity grew with the popularity of Puranic Hinduism [30]. Casteism in society split it up indivisibly [31].

Hardy [32] points out the increased resources which were made available during the $10^{\text {th }}$ century. This was due to the upsurge in trade, irrigation methods and agriculture. This allowed larger temples to be built.

\subsubsection{Temples of the Kalyan Chalukyas}

The temples grew more elaborate than during the earlier dynasties [33] encouraged by royal patronage [34]. The early temple plans are square in shape, while the later phase shows variations made on the basic square. The stellate shape of the sanctum is also followed by the shape of the plinth (Figs. $7 \& 8$ ). The increased surface area is adorned with carvings. The walls of the goodh mandap now give way to open pillared mandaps. With detailed additions to the pantheon, vahan mandaps (vehicles of the deity) were added axially before the entrance porch of the temple. The garbha-grha, antaral and the mandap, lie along the same axis, and are equal in width [35]. The pradakshina path is not always present.

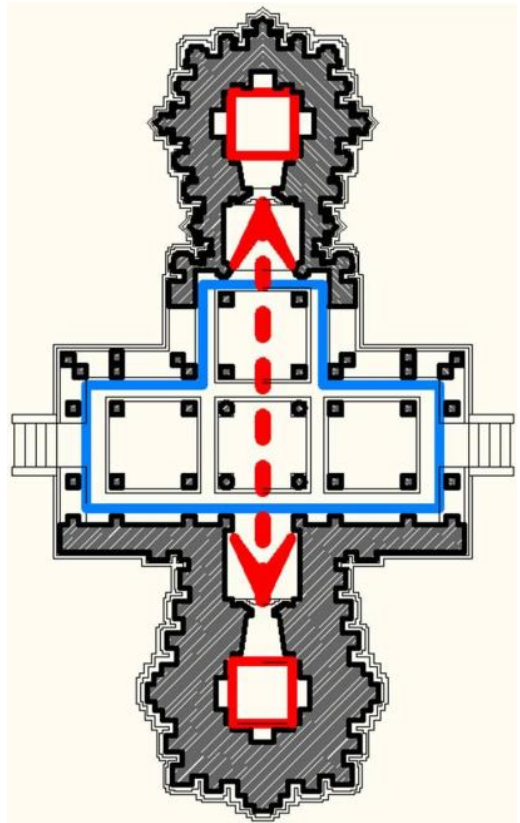

Figure 7: Jodu Kalash, Sudi (1060 CE) [74]

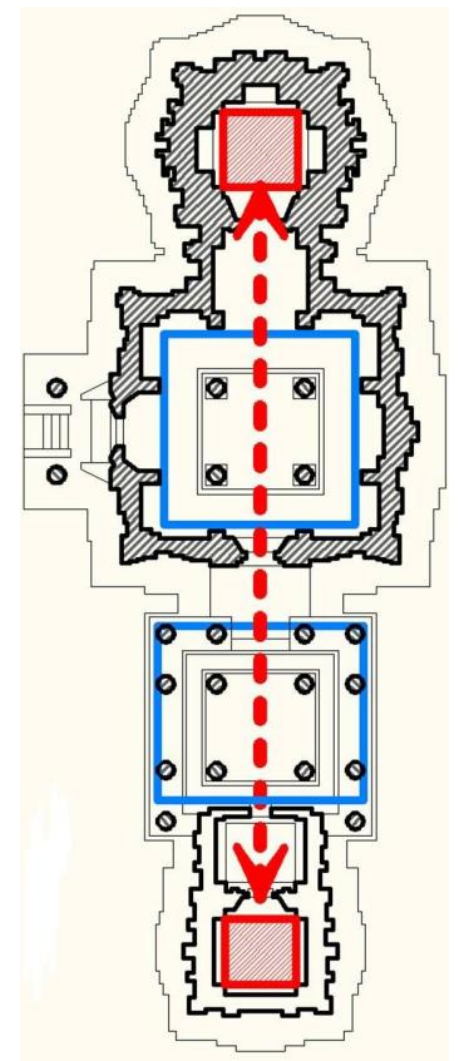

Figure 8: Kashi Vishveshwar, Lakkundi (1030 CE) [75]

\subsection{Hoysalas of Dwarasamudra (11-14 CE)}

The Hoysalas of Dwarasamudra were, originally the feudatories of the Kalyan Chalukyas. They held a large part of Karnataka and were politically prominent in south India [36]. Cultural achievements in the arts and crafts are known to be remarkable, and pursued even by royalty. Women held a high status and held administrative posts. They granted endowments to build temples [37]. This background gave rise to a landmark form of temple architecture in southern India. While the Hoysala rulers followed Vaishnavism and Shaivism, equal patronage was given Jainism and other religions [38], [39]. Ramanuja (1017-1137 CE) of Tamil Nadu, converted of Vishnuvardhan (r. 1108-1142) from Jainism to Vaishnavism [40]. At this time, there was a rise in the practice of elaborate rituals of worship in temples [41]. 


\subsubsection{Temples of the Hoysalas}

The Hoysalas had established a fully-grown style of temple architecture prior to the Vijaynagar rule. They had started building temples since they were under the Kalyan Chalukas. The composition of the temple plan and other architectural persuasions was carried over [42]. An important reason that gave the thrust to the modifications in the temple design, is the making of utsav murtis (bronze idols), crafted during this period (950 $\mathrm{CE}$ onward), for taking out during the festival processions [43]. Consequently, this period sees the forming of a "temple complex", within prakara walls and the provision of appurtenant spaces, which were necessary for conducting the various associated rituals (Fig. 9). Some of these were the kalyan mandap (for the annual marriage festival of the deity and His consort). The prakara walls opened through immense gateways called gopuras. The temple plan remained the simple composition of the ardha mandap, outer mandap with ranga mandap, antaral and garbha-grha, all along the same longitudinal axis and placed upon a high plinth (Fig. 10). These spaces were all square in shape and of the same width. Minor shrines, for the consort of the main deity, etc. were added on with a growing mythological pantheon. Another important development was multi-shrined temples. They were either eka-kuta (one garbha-grha), dvi-kuta (two garbha-grhas), tri-kuta (three garbhagrhas), chatush-kuta (four garbha-grhas) or pancha-kuta (five garbha-grhas) [44]. These multiple sanctums would be placed around a shared or multiple ranga mandaps. The open, pillared outer hall was composed of modulations of the square grid as also seen in the stellate plans. The pradakshina path is open or nirandhar, on the plinth itself, around the sanctum.
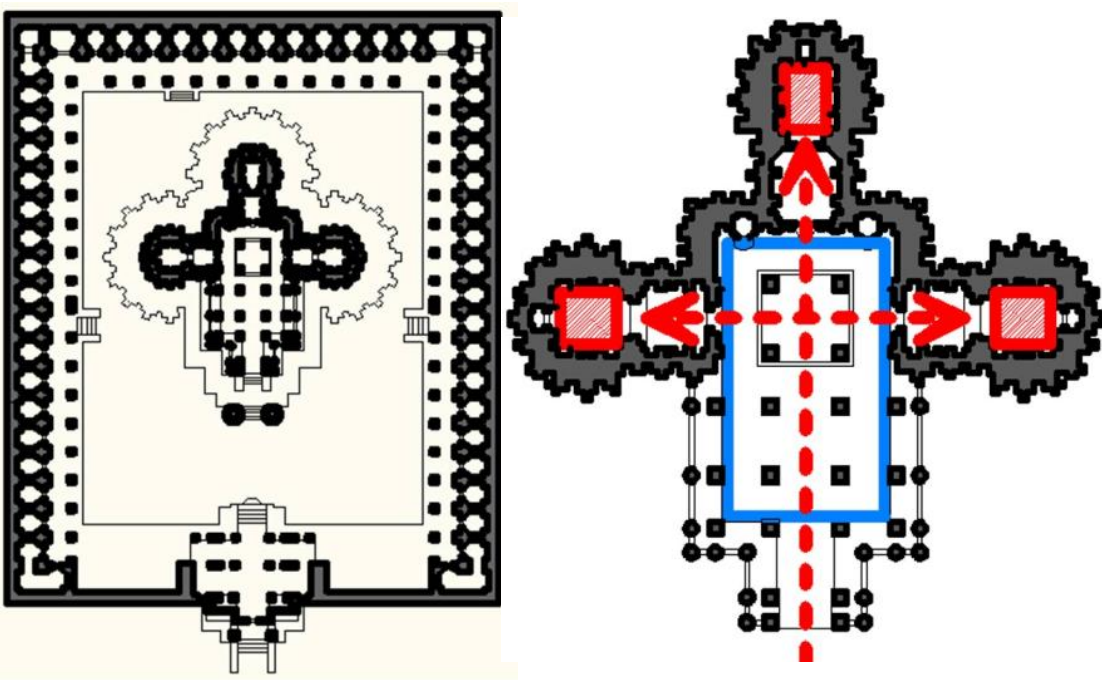

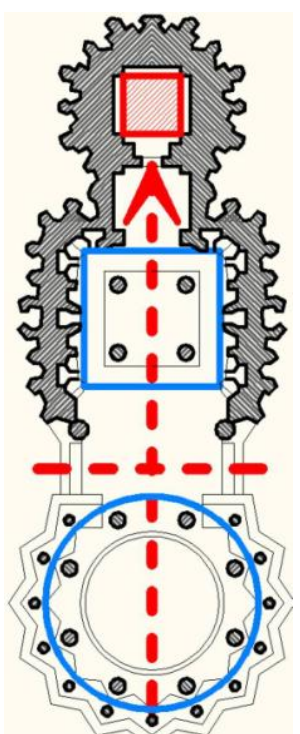

Figure 10: Ishwar, Arsikere (13th cent.) showing a stellate plan of the outer open pillared hall [77]
Left: Prakara wall with peripheral minor shrines and gopuram

Right: Tri-kuta shrines of the main temple [76]

\subsection{Sangama Dynasty (Pre- Vijaynagar) (14-15 CE)}

The Sangamas were the first of the four ruling dynasties of Vijaynagar [45]. Their rule was beset by conflict with Bahmani invasions and only residual resources could be employed for public works and templebuilding [46].

\subsubsection{Temples of the Sangamas}

Various religions, including Jainism and Islam were practised during the Sangama period [47\}. Verghese [48], [49] explains that local goddesses of tribal origin, like Pampa, were incorporated within the Brahmanical pantheon. This was done by having her marry Virupaksha, a form of Shiva. She was then relegated to a single small shrine in the temple complex. Virupaksha became the tutelary deity of the Sangama dynasty and a well-known pilgrimage centre. This helped the Vijaynagar rulers establish their supremacy over the local population, signified through the overlord-ship of Virupaksha over Pampa.

Typically, the temples of the Sangama period are smaller in size and ornamentation both, to their predecessors and the successors. Michell [50] attributes to the diminishing resources of the patrons available for building activity, during this phase of political turbulence. Most of the Sangama temples are seen on the Hemakuta Hill in Hampi, which maintains their proximity with the Virupaksha temple. These are seen to be of 
the eka-kuta, dvi-kuta and tri-kuta types [51]. These temples maintain the simple composition of having a garbha-grha with a ranga mandap. The multiple sanctums have a common ranga mandap with seating called kaksha asan [52]. The garbha-grha and the ranga mandap are both square in shape, lie along the same axis and have equal widths, adhering to the basic grid.

Usually, these temples do not stand within complexes, but are in the form of individual shrines. The vahan mandap, which had grown to be a regular feature earlier, is not seen here, nor is the pradakshina path. (See Figs. 11 \& 12)

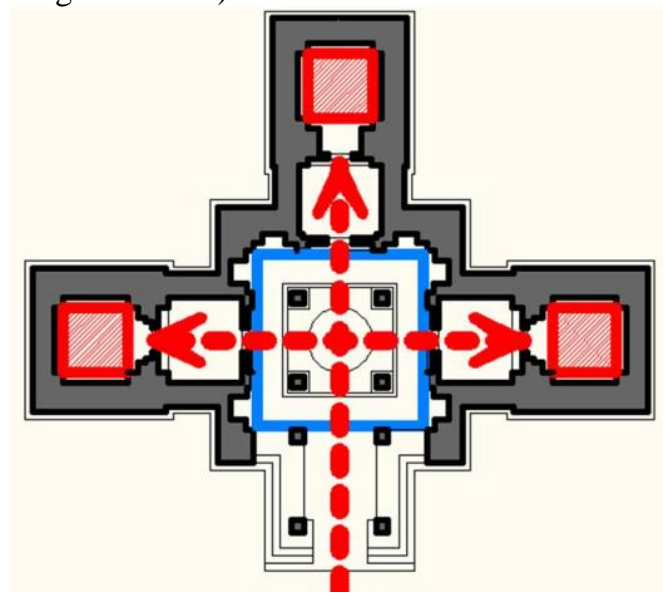

Figure 11: Kampila Raya temple, Hemakuta Hill, Hampi [78]

\subsection{Vijaynagar (Saluva and Tuluva) (15-16 CE)}

The next rule by the Saluva dynasty, was succeeded by the Tuluva dynasty, which was the most powerful one of Vijaynagar [53]. Its strongest ruler, Krshnadevaraya, quashed the Muslin invasions from the north and the Bahmani sultanate in the Deccan. The city of Vijaynagar was built to commemorate this victory.

\subsubsection{Temples of the Vijaynagar Dynasties}

The Rayas of Vijaynagar showed tolerance towards all the religions. The Bhakti movement gathered momentum from advocates like Purandardas (1485-1564 CE). Even though Virupaksha was revered, importance was transferred to Vaishnavism as the state religion [54]. Kersenboom [55] points out the shift from warfare and political conflict, to the stability offered by a strong rule. Temples and places of pilgrimage were patronized and public festivals celebrated with pomp. Elaborate rituals of temple worship were carried out daily as per Agamic prescriptions through appointed officials. This included tasks of administration, duties of worship, dance and music and menial tasks [56]. Michell [57] and Verghese [58] explain that the magnificence of the temples and the public festivals correlate to the power of the Deity. This architectural analogy served the Tuluvas to display their strength and stability to both, their empire and their enemies, through the "scale, elaboration and standardization" of their temple architecture.

The plan of the earlier smaller temples now transformed into a larger and more elaborate complexity of spaces during this period [59]. These were in proportion to the intricate ceremonies and religious procedures required to be carried out. The focus shifted from the sanctum, to the outlying areas [60]. This was due to the importance given to the public festivals and ceremonies held in the temple complex which increased its visibility and importance in the public eye. There were colonnaded pathways and street markets for ceremonial processions of the utsav murtis; gigantic gateways called raya gopurams (named after the rulers) which were taller than the main shikhar, and could be seen from a great distance away. An entirely new innovation was a large hall called the maha ranga mandap. This was a large pillared hall with an open central space for public performances of music and dance. These halls were built to celebrate coronations or military victories. Examples are the maha ranga mandaps built by Krshnadevaraya, in the Virupaksh and by Vira Narasimha in the Vitthal temple [61]. Some other mandaps added were the uyyäle-mandap (for the swing-festival), utsav mandap (for the festive rituals) and the sangit mandap (for playing music to the deity). Despite these elaborations, the composition of the plan retained its axial arrangement. With the increase in scale, the ranga mandap and the garbha-grha both grew larger, yet maintained their proportions in relation to each other, that is, they had the same width and followed the same grid. The pradakshina path around the sanctum was enclosed or sandhar and a regular feature, in keeping with the ritualistic activities. (See Figs. $13 \& 14$ ) 


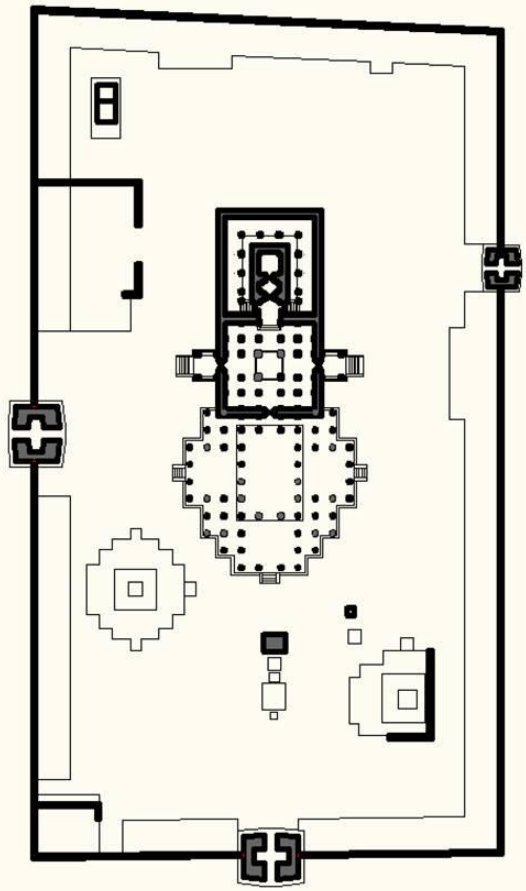

Figure 13: Vitthal temple, Hampi (1513 CE) [80] Left: Complex of Vitthal, Hampi

Right: Main temple of Vitthal

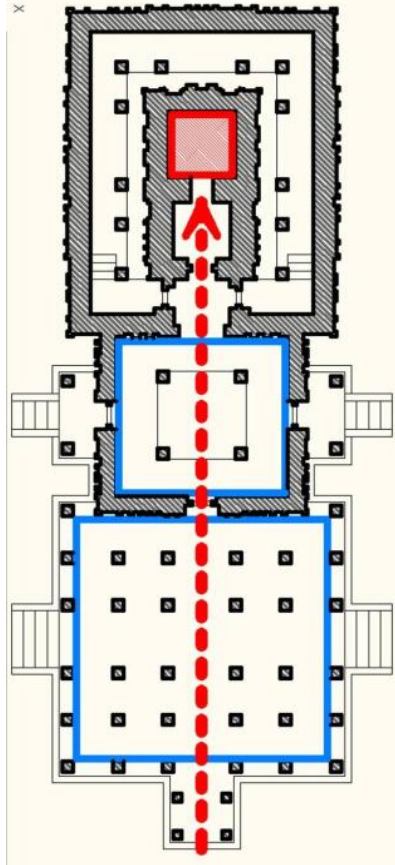

In 1565, Vijaynagar finally fell to Muslim armies, never to recover [62], [63]. The final dynasty of the Aravidus established their rule in Tamil Nadu and Andhra Pradesh, until it finally ended in 1650 due to the East India Company [64].

\section{INFERENCES}

The following table shows the correlation of the contemporary religious and political factors with the corresponding state of evolution of the axial temple plan:

Table 2: Correlation of the contemporary religious and political factors and the temple plan [67]

\begin{tabular}{|l|l|l|l|}
\hline No & Dynasty & Religious and Political Factors & Temple Plan \\
\hline 1 & $\begin{array}{l}\text { Badami Chalukya } \\
(535-757 \mathrm{CE})\end{array}$ & $\begin{array}{l}\text { Effort to find a temple design to } \\
\text { satisfy needs of simple rituals of } \\
\text { worship and of a place for } \\
\text { congregation }\end{array}$ & $\begin{array}{l}\text { Basic plan see- pillared, enclosed } \\
\text { hall, attached cella and pillared } \\
\text { verandah; no antaral }\end{array}$ \\
\hline 2 & $\begin{array}{l}\text { Rashtrakutas of } \\
\text { Malkhed } \\
\text { saguna (visible) form of God. This } \\
\text { was given importance like royalty, as } \\
\text { distinct from the congregation }\end{array}$ & $\begin{array}{l}\text { Mandaps are wider than the garbha- } \\
\text { grha } \text { Both are now invariably square } \\
\text { in shape and divided by a constricted } \\
\text { antaral }\end{array}$ \\
\hline 3 & $\begin{array}{l}\text { Kalyan Chalukyas } \\
(973-1198 \text { CE) }\end{array}$ & $\begin{array}{l}\text { Rise of mythological pantheon and } \\
\text { excessive modes or worship; increase } \\
\text { in casteism }\end{array}$ & $\begin{array}{l}\text { Elaborate geometry used to develop } \\
\text { an ornate exterior; larger surface used } \\
\text { for depiction of pantheon; } \\
\text { pradakshina path seen; open, pillared } \\
\text { mandaps instead of an enclosed one. } \\
\text { Antaral is now a specific space for } \\
\text { segregation of the divine from the } \\
\text { mundane }\end{array}$ \\
\hline
\end{tabular}




\begin{tabular}{|l|l|l|l|}
\hline 4 & $\begin{array}{l}\text { Hoysalas of } \\
\text { Dwarasamudra } \\
(1000-1346 \mathrm{CE})\end{array}$ & $\begin{array}{l}\text { Royal patronage shifts from Jainism } \\
\text { to Hinduism; stress on bhakti and } \\
\text { elaborate offerings of sacred dance } \\
\text { and music, even by royal household; } \\
\text { festival processions with the } \text { utsav } \\
\text { murtis; increased mythology }\end{array}$ & $\begin{array}{l}\text { Adoption of a high plinth to set off } \\
\text { the stellate plan of the temple; open } \\
\text { and enclosed mandaps; secondary } \\
\text { shrines and mandaps added for other } \\
\text { functions, prakara } \text { walls and } \\
\text { gopurams added; multiple shrines }\end{array}$ \\
\hline 5 & $\begin{array}{l}\text { Sangama } \\
(1336 \text { to } 1485 \mathrm{CE})\end{array}$ & $\begin{array}{l}\text { Modest resources available due to } \\
\text { political conflict; existing pantheon } \\
\text { continued }\end{array}$ & $\begin{array}{l}\text { Temples reduced in scale and range; } \\
\text { limited to garbha-grha and ranga } \\
\text { mandap; multiple shrines }\end{array}$ \\
\hline 6 & $\begin{array}{l}\text { Vijaynagar } \\
\text { (Saluva and Tuluva) }\end{array}$ & $\begin{array}{l}\text { Stable and strong empire; elaborate } \\
\text { rituals and public displays of festivals } \\
\text { and processions to create "visual } \\
\text { markers " of might }\end{array}$ & $\begin{array}{l}\text { Single shrined, but spectacular } \\
\text { increase in scale and volume; } \\
\text { addition of several features- maha } \\
\text { ranga mandap, colonnaded } \\
\text { procession streets, multiple prakara } \\
\text { walls, gigantic raya gopurams. }\end{array}$ \\
\hline
\end{tabular}

\section{CONCLUSIONS}

The study has shown that there have been continual progressive changes in the plan of the Hindu temples in Karnataka. These can be related to the various transformations of contemporaneous religious and political factors. When religious procedures were evolving from the elementary to the complex, so did the plan. The earliest plan which consisted of the garbha-grha, a sabha mandap and an ardha mandap could accommodate the basic rituals of the nascent Brahmanical religion. As the pantheon and its mythology grew, so did the rituals of worship, and so did the plan. Adding on multiple shrines can be seen as a method to increase the importance of the temple. Agamic rituals were elaborately followed. Hence the architectural elements of the temple plan also took on greater complexity to ensure their fulfilment, as seen in the Hoysala and Vijaynagar periods. The aspect of political influence and the degree of stability during various periods of dynastic rule can also be seen to be correlated to the temple plan. More innovations and complexities are seen to have arisen in the first four dynasties which experienced greater stability. These are in terms of the placement of the garbhagrha, the pradakshina path and the antaral. On the other hand, the Sangama dynasty, in constant conflict, could not adopt the same elaborateness as seen before and after them. However, their temples consisted of the garbhagrha and the sabha mandap, which we may surmise were considered inevitable for following the fundamentals of Agamic worship and rituals in contemporary practice. The Vijaynagar dynasties, having vanquished their enemies, now stood to proclaim their might through their architectural style. Even though their temples were single-shrined, they were made imposing through an increase in scale and in size, both of which conveyed visually the "imperial culture of the age" [65].

Notwithstanding the above aspects, and the materials and methods of construction used, what remained constant was the axial arrangement of the spaces, the proportions of the spaces maintained by the grid and the relation of the various spaces to each other.

\section{REFERENCES}

[1] Geva, Anat, Frank Lloyd Wright's Sacred Architecture: Faith, Form, and Building Technology (New York : Routledge, 2012) 1.

[2] Kramrisch, Stella, The Hindu Temple, Vol. I (New Delhi: Motilal Banarsidass Publishers Pvt. Ltd., (1946) 1996) 143.

[3] Geva, Anat (2012) 1.

[4] Appadurai, Arjun, Kings, Sects and Temples in South India, 1350-1700 A.D. The Indian Economic and Social History Review, 14 (1), 1977, 47-73.

[5] Meister, Michael, W., The Hindu Temple: Axis of Access in Kapila Vatsyayan (Ed.) Concepts of Space: Ancient and Modern (New Delhi: Indira Gandhi National Centre for the Arts1991) 275.

[6] Michell George, Temple Building under Vira Narasimha and Krishnadevaraya and the Formation of an Imperial Architectural Style in R.Gopal (Ed.), Life and Achievements of Sri Krishnadevaraya (Mysore: Directorate of Archaeology and Museums, 2010) 140.

[7] Kramrisch, Stella (1996) p. 163.

[8] Hardy, Adam, The Temple Architecture of India (Great Britain: Wiley, 2007) 223.

[9] Gupte, R.S. Aihole Art and Architecture : A Study of Early Chalukyan Art through Temple Architecture and Sculpture (Bombay: D.B.Taraporevala Sons \& Co. Pvt. Ltd.,1967) 1. 
[10] Dhaky, M.A. \& Michell, George (Eds.), Encyclopaedia of Indian Temple Architecture: (Vol.1. Part 2), South India, Upper Dravidadesa, Early Phase (c. AD 550-1075) (New Delhi: American Institute of Indian Studies, Oxford University Press, 1986) 105,141.

[11] Bolar, Varija R., Temples of Karnataka: An Epigraphical Study (From the earliest to 1060 AD (New Delhi: Readworthy Publications 2010) 3.

[12] Bolar, Varija R. (2010) 3.

[13] Michell, George (Ed.), Encyclopaedia of Indian Temple Architecture: (Vol.1. Part 4), South India, Dravidadesa, Later Phase (c. AD 289-1798) (American Institute of Indian Studies, 2001) 20.

[14] Michell, George, (2001) 77.

[15] Soundara Rajan, K.V., Indian Temple Styles: The Personality of Hindu Architecture (New Delhi: Munshiram Manoharlal, 1972) 40,43.

[16] Soundara Rajan, K.V., Early Temple Architecture in Karnataka and its Ramifications, Research Lectures, New Series No.1 (Dharwad: Kannada Research Institute, 1969) 2,23.

[17] Acharya, Prasanna Kumar, Indian Architecture according to Manasara Silpasastra: Manasara Series 2 (New Delhi: Low Price Publications, (1934) 2011) 198.

[18] Sinha, Ajay J., Imagining Architects: Creativity in the Religious Monuments of India (New Jersey: Associated University Presses, Inc., 2000) 52.

[19] Pattar, Sheelakant, Personal interview with the author, May 2015.

[20] Gupte, R.S. (1967) 45.

[21] Ibid.

[22] Soundara Rajan, K.V., Glimpses of Indian Culture: Architecture, Art and Religion (New Delhi: Sundeep Prakashan, 1981) 9.

[23] Ibid. 5.

[24] Gupte, R.S. (1967) 47.

[25] Soundara Rajan, K.V. (1972) 43.

[26] Altekar, Anant Sadashiv, The Rashtrakutas and their Times, Oriental Series No. 36 (Poona: Oriental Book Agency, 1934) 278-292.

[27] Bolar, Varija R. (2010) 7.

[28] Altekar (1934) 297.

[29] Soundara Rajan, K.V. (1972) 40.

[30] Bolar, Varija R. (2010) 7.

[31] Ismail, K., Karnataka Temples: Their Role in Socio-Economic Life (New Delhi: Sundeep Prakashan, 1984) 14

[32] Hardy, Adam (2007) 32.

[32] Hardy, Adam (2007) 32.

[33] Ibid. 222.

[34] Soundara Rajan, K.V. (1972) 71.

[35] Hardy, Adam, Indian Temple Architecture: Form and Transformation: The Karnata Dravida Tradition (7th to 13th Centuries (New Delhi: Indira Gandhi National Centre for the Arts (IGNCA), Abhinav Publications, 1995).

[36] Bolar, Varija R. (2010) 3.

[37] Ismail, K. (1984) 15.

[38] Ibid. 16.

[39] Soundara Rajan, K.V. (1981-a) 75.

[40] Verghese Anila. Religious Traditions at Vijayanagara: As Revealed through its Monuments (New Delhi: Manohar, American Institute of Indian Studies, 1995) 6.

[41] Soundara Rajan, K.V. (1972) 37.

[42] Ibid. 75 .

[43] Ibid. 36, 37.

[44] Hardy, Adam (1995) 246.

[45] Michell, George, (2001) 4,5,20.

[46] Ibid. 23,47.

[47] Michell, George, (2001) 23,48.

[48] Verghese, Anila (1995) 16-18.

[49] Verghese, Anila. Archaeology, Art, and Religion: New Perspectives on Vijayanagara (Delhi: Oxford University Press, 2000) 94-114.

[50] Michell, George (2001) 5.

[51] Ibid. 21. 
[52] Michell, George (2001) 5,25.

[53] Krishna, Ashima, The Krishna Temple Complex, Hampi : An Explorarion of its Identity as a Medieval Temple in the Contemporary Context, Thesis for Master of Arts, Cornell University, New York, 2009. 16.

[54] Verghese, Anila (1995) 8,16.

[55] Kersenboom, Saskia C., Nityasumangali : Devadasi Tradition in South India (New Delhi: Motilal Banarsidass Publishers Pvt. Ltd., 2011) 38.

[56] Verghese, Anila (1995) 99,100.

[57] Michell, George (2010) 140.

[58] Verghese, Anila (1995) 4.

[59] Verghese, Anila, Krishnadevaraya and his Times (Mumbai: K.R.Cama Oriental Institute, 2013) 136.

[60] Ibid.

[61] Michell, George (2001) 81.

[62] Krishna, Ashima (2009) 16.

[63] Michell, George, (2001) 80.

[64] Krishna, Ashima (2009) 16,17.

[65] Michell, George (2010) 140,141.

\section{SOURCES OF TABLES AND DIAGRAMS}

[66] Table 1: As mentioned in the references

[67] Table 2:: Authors

[68] Figure 1: Fig. GP-4, Gupte, R.S. (1967) 18.

[69] Figure 2: Fig. 52 c, Hardy, Adam (1995) 449.

[70] Figure 3: Fig. 51, b \& c, Ibid. 448.

[71] Figure 4: Fig. 48, Ibid. 445.

[72] Figure 5: Fig.41, Dhaky, M.A. (Ed.), Encyclopaedia of Indian Temple Architecture: (Vol.1. Part 3), South India, Upper Dravidadesa, Later Phase (c. AD 973-1326) (New Delhi: American Institute of Indian Studies, Indira Gandhi National Centre for the Arts, 1996) 57.

[73] Figure 6: Fig. 1.4, Hardy, Adam (2007) 14.

[74] Figure 7: Fig.37, Dhaky, M.A. (1996) 52.

[75] Figure 8: Fig. 66, Ibid. 98,99.

[76] Figure 9: Pl. 2, Suresh, K.M., Temples of Hampi (and its Environs) (Delhi: Bharatiya Kala Prakashan, 2003) 140.

[77] Figure 10: Fig. 78b, Hardy, Adam (1995) 475.

[78] Figure 11: Fig. 1, Michell, George (2001) 8.

[79] Figure 12: Pl. 2, Suresh, K.M. Temples of Hampi (Delhi: Bharatiya Kala Prakashan, 2003) 140.

[80] Figure 13: Fig. 37, Michell, George (2001) 104.

[81] Figure 14: Fig. 41, Ibid. 108. 